\title{
ZALEŻNOŚĆ DIECEZJI WROCEAWSKIEJ OD METROPOLII GNIEŹNIENSKIEJ W OPINII KAPITUŁY WROCŁAWSKIEJ Z DNIA 5 CZERWCA I654 ROKU
}

30-lecie organizacji kościelnej na Ziemiach Zachodnich i Północnych Polski oraz stabilizacyjne decyzje papieża Pawła VI z dnia 26 czerwca 1972 roku, zamykające okres tymczasowości administracji kościelnej na tych Ziemiach, kierują myśli nasze do przeszłości, kiedy Ziemie te narażone na duże trudności, przechodzić musiały różne procesy wywoływane zmianami politycznymi. Mamy tu na myśli przede wszystkim archidiecezję wrocławską, gdzie procesy te przybierały formę specyficzną.

Diecezja wrocławska jako kościelna jednostka organizacyjna od chwili swego powstania poddana została jako biskupstwo sufraganalne metropolii w Gnieźnie. Utworzona w roku 1000 w czasie zjazdu Bolesława Chrobrego $z$ cesarzem Ottonem III u grobu św. Wojciecha w Gnieźnie, spowodowała jak najściślejsze połączenie Śląska z Polską nie tylko pod względem państwowym, lecz także pod względem administracji kościelnej. Współczesny tym wydarzeniom kronikarz Thietmar, biskup merseburski, nie omieszkał odnotować, że założonej w 1000 roku w Gnieźnie metropolii poddano biskupa ,kołobrzeskiego Reinberna, krakowskiego Poppona i wrocławskiego Jana" 1 . Formalnie twórcą nowej metropolii i należącej do niej diecezji wrocławskiej był papież Sywester II i cesarz Otto III. Falktycznie jednak było to dzieło władcy polskiego Bolesława Chrobrego, który diecezjom wyznaczył granice, stolice i uposażenie, a przez założenie własnej polskiej metropolii przekreślił pretensje sąsiedniej metropolii w Magdeburgu do poddania sobie ziem polskich 2. Zależność Wrocławia od Gniezna była ścisła do połowy XIV wieku.

1 Kronika Thietmara, tłum. J. Jedlicki, Poznań 1953, 206.

2 Silnicki T., Dzieje $i$ ustrój Kościoła katolickiego na Slq̨sku do końca wieku XIV, Warszawa 1953, 15. 
Potem na skutek wzrostu niemczyzny na Śląsku i zmian warunków politycznych nastąpiło rozluźnienie stosunków. Niejednokrotnie też i przez różne czynniki podejmowane były próby oderwania diecezji wrocławskiej od Gniezna. Dążności separatystyczne przejawiali władcy czescy, zamierzający przyłączyć diecezję wrocławską do metropolii praskiej. Węzły łączności usiłowali przerwać niektórzy biskupi wrocławscy, nie uznający często w praktyce zwierzchnictwa arcybiskupów gnieźnieńskich. Wpływ Gniezna na sprawy diecezji wrocławskiej zmniejszał się też na skutek kurczenia się władzy metropolitów w Kościele Powszechnym. Mimo jednak przeróżnych prób o charakterze najczęściej politycznym, nie udało się, przynajmniej aż do XVIII wieku, przerwać wyraźnie prawnoformalnej łączności kościelnej Wrocławia i Gniezna. Przez ponad osiem wieków, mimo zmieniających się warunków politycznych, łączność ta i zależność została w zasadzie zachowana. Wprawdzie od połowy XVII wieku zależność ta była raczej prawna aniżeli faktyczna. W dokumentach papieskich z 1732 i 1748 r. znajdujemy wzmianki, w których diecezja wrocławska potraktowana została jako bezpośrednio zależna od Stolicy Apostolskiej, choć nie brak też przeciwnych dowodów ${ }^{3}$. Dopiero jednak na mocy bulli cirkumskrypcyjnej papieża Piusa VII De salute animarum z dnia 16 lipca 1821 roku diecezja wrocławska stała się diecezją egzempcyjną, podporządkowaną bezpośrednio Stolicy Apostolskiej 4 . Tym przywilejem egzempcji cieszyła się aż do roku 1929, czyli do czasu zawarcia konkordatu z rządem pruskim przez Stolicę Apostolską, kiedy to Wrocław stał się sam metropolią z arcybiskupem na czele.

W dziejach łączności kościelnej Wrocławia z Gnieznem dużą rolę odegrała kapituła katedralna wrocławska. Pod jej to kierunkiem duchowieństwo diecezjalne pracowało od początku nad chrystianizacją Śląska. Stanowiła ciało liczne, możne i dostojne, a w organizmie diecezjalnym zajmowała prawne miejsce tuż po biskupie. Faktyczna jej rola bywała zmienna, zależnie od siły, jaką sama reprezentowała, lub od biskupa, od stosunków w diecezji i w kraju. Była ciałem autonomicznym, mającym pewne prawa i obowiązki. Uważana była za senat biskupa, przy którym spełniała doniosłe funkcje w rządzie diecezją. Rola jej wobec

3 Por. Kumor B., Granice metropolii gnieźnieńskiej $i$ jej sufraganii $w$ okresie przedrozbiorowym, „Roczniki Teologiczno-Kanoniczne”, 13 (1966), $\mathrm{nr} 4$, 15; Muller W., Diecezje w okresie potrydenckim, w: Kościót w Polsce, t. 2, Wieki XVI-XVIII, Kraków 1970, 71; Urban W., Dobrze wypetnione zadanie, „W drodze”, 2 (1974), nr. $7,8$.

4 Muller W., dz. cyt., 72, wypowiada opinię, że formalna egzempcja diecezji wrocławskiej co najmniej od r. 1748 wydaje się trudna do podważenia. Procesy informacyjne i relacje arcybiskupów gnieźnieńskich mogą - zdaniem autora świadczyć najwyżej, że metropolici i polskie kręgi kościelne nie rezygnowały ze swoich pretensji do Wrocławia. Por. też Winowski L., Stosunki między biskupstwem wrocławskim a metropolia gnieźnieńska $w$ latach 1740-1748, „Przegląd Zachodni", 11 (1955, nr 1) 613-692; oraz Kumor B., dz. cyt., 12-16. 
biskrupa polegała na udzielaniu mu zgody dla przedsiębranych przezeń niektórych czynności, zwłaszcza natury prawodawczej i majątkowej, lub rady - co uwydatniało się szczególnie przy nakładaniu cenzur lub decyzjach z zakresu polityki kościelnej. Najcenniejszym prawem kapituły był jednak przysługujący jej u ybór biskupa.

Wielkie znaczenie kapituły wrocławskiej w diecezji zaznaczyło się silnie już w wieku XIV. Rozbudowała ona wtedy swą organizację, poszerzyła i utrwaliła swe prawa i urosła pod względem faktycznego znaczenia. Biskup wrocławski Wacław (1382-1417) w osobnym statucie z 1383 roku rozszerzył prawa kapituły w czasie wakansu na stolicy biskupiej i uzależnił objęcie władzy przez nowego biskupa od uprzedniego zaprzysiężenia przezeń praw i przywilejów kapituły ${ }^{5}$. Wiek XIV stanowi już początek przewagi żywiołu niemieckiego na ziemi śląskiej, co w zdecydowany sposób zaznacza się również w składzie osobowym kapituły. Nie działała ona na ogół sama. Sprzymierzona była w swej działalności z silnym mieszczaństwem wrocławskim, bogatym i przeważnie już niemieckim, oraz z królem czeskim, który wygrywał dla swych interesów politycznych napięcie $\mathrm{w}$ Kościele śląskim ${ }^{6}$. Sprawiało to, że kapituła nie kryla swej sympatii do wszystkiego, co niemieckie, a wrogości do tego, co polskie. Tak na przykład na kapitule generalnej w dniu 1 października 1435 roku za rządów biskupa Konrada Oleśnickiego (1417-1447) wydano statut de extraneis non admittendis, który wykluczał od godności i kanonii kapituły wrocławskiej wszystkich nieślązaków, przez których rozumiano głównie Polaków. W statucie z 1498 roku stwierdzono już wyraźnie, że do grona kapituły nie może być przyjęty żaden Polak, Rusin, Litwin, Mazowszanin z powodu nieznajomości języka niemieckiego oraz by nie dawać sposobności do siania sporów i nieprzyjaźni ${ }^{7}$.

Jedną z najbardziej przykrych i uciążliwych dla kapituły spraw była oczywiście istniejąca mimo wszystko zależność biskupstwa wrocławskiego od polskiej metropolii gnieźnieńskiej. Nic zatem dziwnego, że od czasu do czasu daje ona widomy wyraz swoim separatystycznym dążeniom do uniezależnienia się od metropolii gnieźnieńskiej. Pierwsza poważniejsza próka separacji podjęta została w połowie XIV wieku za panowania ostatniego z Piastów, w związku ze sprawą płacenia świętopietrza dla Stolicy Apostolskiej. Druga - miała miejsce pod koniec życia ostatniego z Jagiellonów. Jedna i druga próba zakończyła się niepowodzeniem ${ }^{8}$.

5 Por. Silnicki T., dz. cyt., 325, 336-346.

- Rogalski A., Kościót katolicki na Sląsku, Warszawa 1955, 23.

7 Urban W., Zarys dziejów diecezji wrocławskiej, Wrocław 1962, 30.

8 Próby te omówiliśmy w osobnym opracowaniu drukowanym w dwóch częściach na łamach kwartalnika prawno-historycznego „Prawo Kanoniczne” w artykule Separatystyczne dqżenia kapituły wrocławskiej do uniezależnienia się od metropolii gnieźnieńskiej, 9 (1966), $\mathrm{nr} 3-4,185-197$ i 12 (1969), nr 1-2, 3-34. 
Gwałtowne szerzenie się luteranizmu na Śląsku sprawiło, że zniemczona całkowicie kapituła wrocławska zwracała się często do Polski o pomoc i to zarówno do swego arcybiskupa gnieźnieńskiego, jak i do króla polskiego ${ }^{9}$. Kiedy jednak niebezpieczeństwo grożące Habsburgom minęło i syłuację spowodowaną reformacją opanowano, na nowo podejmowano w kurii rzymskiej zabiegi zmierzające do oderwania diecezji wrocławskiej od Gniezna.

Dogodną sposobność do uniezależnienia się od metropolity gnieźnieńskiego znalazla kapituła wrocławska w pierwszej połowie XVII wieku. Pod wpływem papieża i cesarza Ferdynanda II, który był szwagrem króla polskiego Zygmunta III Wazy, kapituła czuła się zmuszona wyłbrać na biskupa wrocławskiego syna tegoż króla - Karola Ferdynanda Wazę (1625-1655). Początkowo $z$ uwagi na małoletność biskupa fakty.czną władze $\mathrm{w}$ diecezji sprawowali administratorzy wybrani z grona kapituly. Później jednak, kiedy biskup sam przejął władzę w diecezji, kapituła obawiała się wzrostu wpływów polskich i odnowienia zależności metropolitalnej od Gniezna. Spór o jurysdykcję metropolity gnieźnieńskiego nad diecezją wrocławską przenoszony jest przez nią coraz bardziej z płaszczyzny kościelnej na polityczną. W roku 1638 kanonik Fryderyk Berg opracował z upoważnienia kapituły specjalny memoriał w sprawie uprawnień metropolitalnych arcybiskupa gnieźnieńskiego nad Wrocławiem. Memoriał ten wysłano do króla czeskiego i zarazem cesarza Ferdynanda III (1637-1657) z prośbą o obronę przed roszczeniami Gniezna, a dnia 20. Iutego 1641 roku kanonik Jan Dest referował sprawę egzempcji diecezji wrocławskiej na sejmie Rzeszy w Regensburgu ${ }^{10}$. Kiedy mimo wszystko Wrocław formalnie pozostał nadal w granicach metropolii polskiej, kapituła z uporem kontynuowała swe wysiłki zmierzające do zrzucenia zależności metropolitalnej od Gniezna.

Nowej sposobności dostarcza jej zatarg z biskupem Karolem Ferdynandem na tle synodu diecezjalnego, który się odbył w Nysie w dnịach 26-28 maja 1653 roku. W związku z tym kapituła przygotowała nowy: memoriał, w którym pod datą 5 czerwca 1654 roku zwraca się znowu nie do papieża, lecz do cesarza ze skarga na biskupa. Oto do komisji przygotowującej synod książę biskup obok swego sekretarza kanonika płockiego Mateusza Jagodowicza, powołał dwóch kanoników gnieźnieńskich - Grabowskiego i Nieborowskiego. Udzial duchownych polskich, zwłaszcza kanoników gnichnieńskich, uważa kapituła za kamień obrazy i określa jako sprzeczny z uświęconymi zwyczajami oraz jako niebez-

9 Por. Piwarski K., Historia Slaska w zarysie, Katowice-Wroclaw 1947, 199; Rogalski A., dz, cyt., 36-41.

10 Por. Heyne J., Dokumentierte Geschichte des Bisthums und Hochstiftes Brestau, t. 3, Breslau 1868, 827-830. 
pieczny dla zasady i dla podtrzymania egzempcji spod władzy metropolitalnej Gniezna: ,quia ex actis constat dominos Polonos nostrae exemptioni iam pridem legitimis modis quaesitae, maxime Gnesnenses, infensos esse, suam superioritatem et nostram subiectionem recentesque actus possessorios contra Regni Bohemiae iura quaerere". Uchwalone na synodzie diecezjalnym statuty kapituła uważa za niezgodne $\mathrm{z}$ prawem powszechnym, $z$ ustawodawstwem świeckim i zwyczajami diecezji, w związku z czym sugeruje cesarzowi zastosowanie wobec nich veto cesarskiego ${ }^{11}$. Do memoriału dołączona została cała seria załączników, mających niekiedy charakter obszernych i wyczerpujących traktatów kanonistycznych, zaopatrzonych $\mathrm{w}$ aparat naukowy ${ }^{12}$. Przedmiotem naszego zainteresowania jest załącznik $F$, który zawiera opinię kapituły na temat wpływów dekretów soboru trydenckiego na stosunek biskupstwa wrocławskiego do metropolii gnieźnieńskiej ${ }^{13}$. Spróbujmy prześledzić tok myśli autorów $\mathrm{w}$ tym dokumencie.

$\mathrm{Na}$ wstępie kapituła stawia kwestię, które z dekretów trydenckich dotyczą zwierzchnictwa metropolity gnieźnieńskiego nad biskupem wrocławskim. Dekretów tych wymienia osiem:

1. Sess. 13 c. 2 de ref. - w sprawie apelacji od wyroku biskupa do metropolity;

2. Sess. 22 c. 7 de ref. - co do obowiązku stosowania konstytucji Romana Innocentego IV w sprawach apelacyjnych;

3. Sess. 23 c. 1 de ref. - który upoważnia metropolitę do przeprowadzania dochodzeń odnośnie rezydencji biskupów w diecezjach;

4. Sess. 24 c. 2 de ref. - dotyczący zwolywania co trzy lata synodów prowincjonalnych przez metropolitów;

5. Sess. 24 c. 3 de ref. - na mocy którego metropolita może dokonywać wizytacji swoich diecezji sufraganalnych w sprawach przedłożonych synodowi prowincjonalnemu;

6. Sess. 24 c. 5 de ref. - według którego poważniejsze sprawy kryminalne biskupów mają być rozpatrywane przez samego papieża, natomiast sprawy mniejszej wagi przez synod prowincjonalny;

11 Relatio ad Synodum Nissae 26 May celebratae anno 1653, Sambl. Beylagen A, B, C, D, E, F, G, H $\mathrm{H}^{2}, \mathrm{I}, \mathrm{K}, \mathrm{L}, \mathrm{M}, \mathrm{N}, \mathrm{O}, \mathrm{P}, \mathrm{Q}, \mathrm{R}$, praes. 5 Juny anno 1654. Deutsches Zentralarchiv NIerseburg R. 46 B n. 164 e, f. 278-287 V.

12 Por. Sawicki J., Concilia Poloniae, X, Synody diecezji wroclawskiej $i$ ich statuty; Wroclaw-Warszawa-Kraków 1963, 282-323.

13 Odnalezienie zarówno memoriału jak i załączników jest zasługą wybitnego badacza polskiego ustawodawstwa synodalnego, prof. dr Jakuba Sawickiego, któremu dziękuję na tym miejscu za łaskawe udostępnienie mi mikrofilmu załącznika oraz zachętę do jego opracowania, tym bardziej, że nie był on dotąd nigdzie publikowany. 
7. Sess. 24 c. 16 de ref. - o ustanowieniu wikariusza kapitulnego przez kapitułę w ciągu ośmiu dni wakansu na stolicy biskupiej, po upływie zaś tego terminu - przez metropolitę;

8. Sess. 24 c. 20 de ref. - w myśl którego sprawy kościelne rozpatrywane przez trybunał diecezjalny pierwszej instancji, a nie ukończone w ciągu dwóch lat, mają być przedłożone sądowi metropolitalnemu.

$\mathrm{Z}$ kolei kapituła stawia nową kwestię: czy wobec powyższego biskup wrocławslí może legalnie utrzymywać swoją egzempcję spod władzy metropolitów gnieźnieńskich? Odpowiedzią na to pytanie są dwa wnioski:

Pierwszy - dotyczy historycznej strony zagadnienia. Jest rzeczą niewątpliwą, potwierdzoną przez dokumenty historyczne, że $\mathrm{w}$ dawnych czasach biskupstwo wrocławskie podlegało metropolicie gnieźnieńskiemu.

Drugi wniosek podaje jako pewnik (,,certum est”), że obecnie arcybiskup gnieźnieński nie posiada już praw metropolitalnych wobec biskupa wrocławskiego korzystającego $z$ prawa egzempcji, ponieważ od co najmniej stu lat metropolita gnieźnieński nie wykonał żadnego aktu płynącego $\mathrm{z}$ jego uprawnień. Argumenty na powyższą tezę ujęte zostały w dziesięciu punktach. Mianowicie:

1. Chociaż metropolicie przysługiwało prawo konsekrowania biskupa wrocławskiego, nie można wykazać, by arcybiskup gnieźnieński z władzy tej wobec biskupa wrocławskiego korzystał od co najmniej 40 lat i aby biskup wrocławski to jego prawo respektował.

2. Chociaż w konsekracji metropolity zobowiązani byli brać udział wszyscy biskupi sufragani, okazało się, że biskup wrocławski w kilku wypadkach od 40 lat ani nie był wzywany ani też się nie stawił.

3. Chociaż biskup sufragan, który nie był konsekrowany w kraju metropolity, w ciągu trzech miesięcy zobowiązany był złożyć wizytę własnemu metropolicie celem otrzymania od niego instrukcji, lub też winien był usprawiedliwić się $\mathrm{z}$ niedopełnienia tego obowiązku podając prawną przeszkodę, nie można dowieść, aby biskupi wrocławscy obowiązkowi temu zadośćczynili, lub też żeby $\mathrm{z}$ powodu zaniedbania tego obowiązku byli kiedykolwiek przez metropolitę upominani.

Dodajmy, że na przykład biskup Konrad Oleśnicki (1417-1447) przy objęciu stolicy biskupiej złożył obediencję tylko papieżowi z pominięciem metropolity. Kiedy w roku 1427 na zlecenie papieża Marcina V arcybiskup gnieźnieński Wojciech Jastrzębiec przedsięwziął wizytację całej prowincji kościelnej, biskup Konrad starał się udaremnić jego plany. Gdy jednak biskupowi zagroziło w 1428 roku poważne niebezpieczeństwo husyckie, przypomniał sobie gnieźnieńskiego metropolitę i prosił go o pomoc, a nawet nazwał go ,principalis pastor ecclesiae" ${ }^{14}$.

14 Por. Urban W., Zarys dziejów..., 20. 
4. Chociaż metropolita winien nakazać swoim sufraganom stosowanie się do przepisów prawa prowincjonalnego, to jednak nie da się udowodnić, by metropolita gnieźnieński od co najmniej 40-60 lat z tej władzy korzystał.

5. Chociaż arcybiskup winien był na piśmie udzielać biskupowi sufraganowi zezwolenia na przebywanie poza diecezją, faktem jest, że nikt z kanoników wrocławskich nie przypomina sobie tego ani też nie znajduje to potwierdzenia w aktach.

6. Chociaż metropolita ma władzę karania tych, którzy nie zachowują zwyczajów metropolii w służbie Bożej, jednak można wykazać, że w diecezji wrocławskiej metropolita gnieźnieński od 40-60 lat z tej władzy nie korzystał.

7. Chociaż arcybiskup jako delegat papieski może zwoływać zakonników swojej prowincji podległych bezpośrednio Stolicy Apostolskiej, a winnych zaniedbania ścigać stosownie do przepisów trydenckich, to jednak metropolita gnieźnieński nie jest $w$ stanie udowodnić, by z władzy tej korzystał od co najmniej 100 lat.

8. Chociaż arcybiskup może wyznaczyć wikariusza kapitulnego w diecezji sufraganalnej, jeśli kapituła nie dokonała wyboru w ciągu ośmiu dni po śmierci biskupa, i chociaż biskupia stolica wrocławska często bywała osierocona, to jednak metropolita gnieźnieński nigdy takiego aktu nie podjął. Z tego dostatecznie wynika, że biskup wrocławski swoją egzempcję prawnie uzyskał i znajduje się w jej posiadaniu.

9. Chociaż od wyroku biskupa należy apelować do arcybiskupa, to jednak od co najmniej 100 lat nie skierowano żadnej apelacji do arcybiskupa gnieźnieńskiego, lecz kierowano je do nuncjusza.

To również - zdaniem kapituły - przemawia za przedawnieniem przede wszystkim dlatego, że w żadnym $\mathrm{z}$ wymienionych zaniedbań w stosunku do diecezji wrocławskiej nie miał miejsca jakikolwiek konflikt, nie założono żadnego sprzeciwu, nie podjęto żadnej kontrakcji. Poza tym tego stanu rzeczy nie można przez tyle lat tłumaczyć jakąś niewiedzą arcybiskupa. Skoro zatem nie ma trudności co do possessio naturalis egzempcji przez biskupa wrocławskiego, possessio civilis zaś zostało utracone po upływie 10 lat ${ }^{15}$, przeto jest rzeczą jasną, że metropolita gnieźnieński nie posiada władzy metropolitalnej nad biskupem wrocławskim.

15 Przez possessio naturalis rozumiało prawo rzymskie detencję czyli dzierżenie, które oznaczało fizyczne zawładnięcie rzeczą bez zamiaru zatrzymania jej dla siebie, ale dla innej osoby (animus rem alieno nomine habendi). Possessio civilis natomiast wymagało zachowania się jak właściciel, tzn. z wolą zatrzymania rzeczy dla siebie (animus rem sibi habendi). W tym położeniu jest rzeczywisty właściciel. Posiadanie - possessio wymagało od posiadacza tak fizycznego zawładnięcia rzeczą (corpus), jak i woli zatrzymania rzeczy dla siebie (animus rem sibi habendi). 
10. Chociaż sess. 24 c. 2 soboru trydenckiego stanowi, że synody prowincjonalne winny się odbywać w każdym trzechleciu, a do uczestniczenia w nich zobowiązani są biskupi prowincji bez względu na dziesięciolecie, w którym nie były zwoływane, to jednak i w tym wypadku arcybiskup nie korzystał z przysługującej mu władzy. Jest rzeczą powszechnie znaną, że diecezja tutejsza z uwagi na posiadaną przez siebie egzempcję do dnia dzisiejszego uważała się za zwolnioną od tychże synodów, a przeprowadzała to w formie jak najbardziej nieskrępowanej i bez jakiegokolwiek sprzeciwu ze strony metropolity. Natomiast można wykazać, że biskup wrocławski podejmował niezliczone wprost akty świadczące o posiadaniu egzempcji i w ten sposób na zasadzie ustawowego przedawnienia nabył jej praw. Albowiem w tym właśnie przypadku zwoływane były przez metropolitów gnieźnieńskich liczne synody, a jednak od 40 lat żaden z biskupów wrocławskich nie był do udziału w nich zobowiązany, wzywany, ani też na nie się nie stawiał.

Po tych wywodach kapituła usiłuje wykazać rozumne racje przemawiające za egzempcją. Stwierdza mianowicie, że egzempcji tej domagały się dobro ojczyzny i pokój Niemiec na skutek wojny w 1478 roku między Maciejem - królem Węgier i Czech oraz Kazimierzem - królem polskim. Ten pokój został zagrożony przez polskich ministrów w związku ze zdradą tajemnicy obowiązującej na synodach prowincjonalnych. Chodziło o statut uchwalony na kapitule generalnej za rządów biskupa wrocławskiego Rudolfa, na mocy którego zabroniono dostępu do kanonikatów kapituły wrocławskiej wszystkim Polakom i osobom urodzonym w prowincjach podległych Polsce $z$ uwagi na różnice obyczajowe i językowe ${ }^{17}$. Uchwała ta została podjęta niewątpliwie na życzenie króla Wegier i Czech Macieja, wyrażone w Cornenburgu w dniu świętych Młodzianków 1474 roku ${ }^{18}$, kiedy to zaapelowano do biskupa wrocławskiego, by nie dopuszczał i nie powierzał żadnych beneficjów w Księstwie Sląskim nikomu z Polaków lub osobom pochodzenia polskiego. W wydanym przez króla reskrypcie podano jeszcze, że monarcha zwróci się także do papieża, by nie udzielał prowizji na beneficja śląskie Polakom, ponieważ wielu miejscowych duchownych bardziej zasługuje na to wyróżnienie.

16 W 1479 r. zawarto pokój w Ołomuńcu, na mocy którego Maciej zachowal dożywotnio Morawy, Sląsk i Eużyce, a Władysławowi, najstarszemu synowi Kazimierza Jagiellończyka, pozostały tylko same Czechy. Por. Piwarski K., dz. cyt., 139 i 141.

17 Biskup Rudolf z Rudesheim, z którego czasów pochodzą zredagowane wtedy statuty kapitulne tzw. Statuta Rudolphina, rządził diecezją wrocławską w latach $1468-82$.

18 Było to bezpośrednio po nieudanej wyprawie króla polskiego Kazimierza Jagiellończyka przeciwko Maciejowi. Armia polska wróciła do kraju w grudniu 1474 r. Por. Piwarski K., dz. cyt., 138. 
Kapituła stoi na stanowisku, że nie stanowi żadnej nowości to, iż nie podporządkowuje się diecezji obcemu metropolicie z uwagi na przynależność do różnych państw oraz na różnice obyczajowe i językowe. To samo przecież ma miejsce w Hiszpanii, we Francji i w Dolnych Niemczech, a nawet $\mathrm{w}$ samej Polsce, gdzie nie znajdzie się żadnej diecezji poddanej metropolicie innego kraju, jak to wynika z katalogu diecezji. A chociaż patriarsze akwileńskiemu poddane są diecezje należące do różnych księstw i krajów, to jednak wszystkie te diecezje mówią tym samym językiem. Podobnie nie ma sprzeczności w tym, że według katalogu diecezji w skład archidiecezji trewirskiej wchodzą diecezje Metz, Toul i Verdun, znajdujące się poza granicami. Stan ten jest pozostałością okresu, gdy wspomniane diecezje należały do cesarstwa rzymskiego. Król francuski siłą wymógł, by biskup trewirski zachował nad nimi swą władzę metropolitalną, co zostało potem zagwarantowane specjalnym układem pokojowym z królem francuskim. Natomiast w układzie z Polską czegoś takiego nie zastrzeżono, a zatem przyjąć należy, że ze strony króla polskiego nastąpiła rezygnacja z praw metropolitalnych Gniezna nad Wrocławiem.

Zdaniem kapituły wrocławskiej egzempcji Wrocławia nie stoi na przeszkodzie i to, że granice diecezji w świetle prawa kanonicznego nie mogą ulec przedawnieniu, ponieważ odnośne przepisy $w$ tej sprawie dotyczą sytuacji, kiedy na skutek przedawnienia następuje zatarcie granic. W tym wypadku zaś takiego skutku nie trzeba się obawiać, ponieważ chodzi tylko o to, by diecezji nie poddawać obowiązywalności dawnego prawa, a diecezjan nie zmuszać do uznania zwierzchnictwa gnieźnieńskiego, obcego całkowicie pod względem obyczajowym i językowym. Aby ustrzec się przed takim zatarciem granic, w statutach synodalnych wrocławskich wyraźnie postanowiono, aby osoby duchowne czy świeckie tej diecezji wrocławskiej nie były pociągane do ponoszenia uciążliwych i zbytecznych wydatków oraz do nadmiernych świadczeń rzeczowych i fizycznych ze względu na duże różnice warunków lokalnych. Wskutek tego żaden kapłan, duszpasterz czy inny albo notariusz publiczny, nie może przyjmować bez upoważnienia biskupa wrocławskiego lub jego wikariusza obcych zarządzeń wydanych poza diecezją wrocławską, nie może powodować ich wykonania lub wywieszenia w kościołach, lecz doręczycieli tego rodzaju zarządzeń i posłańców należy pod karą synodalną odesłać do biskupa wrocławskiego lub jego wikariusza generalnego.

Kapituła zwraca ponadto uwagę, że w Polsce biskupi w sprawach doczesnych podlegają sądom ziemskim. Biskup wrocławski natomiast podlega królowi czeskiemu nie tylko w sprawach doczesnych na mocy zależności, lecz poza tym całe Niemcy na mocy przywileju papieskiego w sprawach beneficjalnych i podobnych zobowiązane są stosować się do 
konkordatów niemieckich. W związku z tym sprawa sporna tego rodzaju może być rozstrzygana jedynie między niemieckimi podmiotami tego prawa, a nie może być przenoszona do podmiotów znajdujących się poza tym prawem, co znajduje oparcie w prawie kanonicznym (c. 3, II, 15 in VI-o). Trzeba zważyć i to, że król czeski posiada liczne szczegółowe przywileje oraz otrzymane od papieża dyspensy, gdy tymczasem metropolici gnieźnieńscy będąc ich pozbawieni na próżno rościliby sobie pretensje do rozpatrywania spraw w drugiej czy $w$ pierwszej instancji. W podobnej sytuacji znajdowałby się Niemiec, gdy nie znając przywilejów Królestwa Polskiego uzurpowałby sobie prawo do rozpatrywania sprawy polskiej.

Autorzy memoriału sięgają teraz do reguł prawa międzynarodowego. Stwierdzają, że na mocy układu między Janem Luksemburskim królem czeskim i Kazimierzem - królem polskim, zawartego za pośrednictwem Karola - króla Węgier w roku 1335, Sląsk oderwany został od Polski i przyłączony do Niemiec ${ }^{19}$. Następnie w roku $1339{ }^{20}$ wcielony został do Czech z wszystkimi swoimi prawami i przywilejami na zasadzie cesji uniwersalnej 21. Jak prawo patronatu nad kościołami przechodzi in solidum z cedenta na cesjonariusza, jeśli imiennie nie zostanie wyjęte, tak i egzempcja od władzy cedującej wszelkie prawo przechodzi na cesjonariusza. Cesja bowiem porównywana jest $\mathrm{z}$ manumissio, która uwalnia poddanego od zależności, na przykład niewolnika od władzy pana, któremu podlega. Ta cesja czy manumisja tym bardziej zasługuje tu na uwagę, że nie można zaprzeczyć, iż została ona dokonana za zgodą arcybiskupa gnieźnieńskiego jako prymasa Królestwa. Zgoda ta jest tym pewniejsza, że od owego czasu Polska odmówiła biskupom wrocławskim godności senatorskiej, należnej im na zasadzie prawa wrodzonego i dziedzicznego, co nie mogło nastąpić bez zgody prymasa. Godności tej odmawia się do tej pory, pozbawiając tym samym diecezję wrocławską przysługującego jej splendoru i części dziedzictwa, a pozbawienie to równa się bez wątpienia wydziedziczeniu. Wyzucie $\mathrm{z}$ dziedzictwa zaś uwalnia syna od władzy ojcowskiej i rodzi poczucie krzywdy. Kapituła stwierdza w związku $\mathrm{z}$ tym, że diecezja wrocławska stała się łupem wrogów i to akatolików, którzy okupowali miasto wraz z Ostrowiem Tumskim i rezydencją biskupią, co spowodowało utratę praw ${ }^{22}$. Dopiero przy pomocy

19 Chodzi o układ w Trenczynie, na mocy którego władca czeski rezygnował z pretensji do polskiej korony, a król polski zrzekał się ziem śląskich, będących pod władaniem czeskim.

${ }_{20}$ W r. 1339 dokonało się w Krakowie potwierdzenie umowy trenczyńskiej.

21 W prawie międzynarodowym określa się tym terminem transfer-terytorium, rezygnację państwa cedenta $\mathrm{z}$ suwerenności nad ludnością osiadłą na tym terytorium, które przechodzi pod suwerenność państwa-cesjonariusza (nabywcy).

${ }_{22} \mathrm{Na}$ pomoc protestantom przybył w r. 1630 Gustaw Adolf z armią szwedzką. Szwedzi i zjednoczeni z nimi Sasi dopuszczali się najrozmaitszych gwałtów. 
wojska cesarskiego iure postliminii ${ }^{23}$ diecezja odzyskała wolność i po cichu ponownie wcielona została do królestwa czeskiego $z$ wszelkimi prawami odzyskanymi dzięki berłu cesarskiemu. Dokonało się to bez jakiegokolwiek poparcia arcybiskupa gnieźnieńskiego i pomocy Królestwa Polskiego, a jedynie za pieniądze cesarskie. Daremnie zatem metropolita gnieźnieński chciał wyciągnąć dla siebie korzyści z tej akcji, skoro ani nie uczestniczył $\mathrm{w}$ jej trudzie ani też nie ponosił jej kosztów.

Wyrażając zdziwienie $\mathrm{z}$ powodu pretensji arcybiskupa gnieźnieńskiego i Polski usiłujących odzyskać na drodze prawa zwierzchność nad diecezją wrocławską, kapituła przypomina, żẹ Polska zagarnęła Prusy, a wraz z nimi diecezję warmińską poddaną opiece i władzy papieża. Pretensje polskie do zwierzchności kościelnej na tych ziemiach dopiero wtedy miałyby jakieś uzasadnienie, gdyby Polska przywróciła diecezji warmińskiej na sejmach należną godność senatorską na mocy iure postliminii.

Argumentacja kapituły zmierza ku końcowi. Usiłuje zatem rozprawić się jeszcze $\mathrm{z}$ kilku zarzutami. Pierwszy $\mathrm{z}$ nich to fakt posiadania kiedyś przez Gniezno praw zwierzchności wobec diecezji wrocławskiej, z czego można by domniemywać dalsze ich posiadanie. Zarzut ten, choć prawnie ma duże znaczenie, dopuszcza jednak - zdaniem kapituły - pewne wyjątki. Między innymi przyjmuje się, że na skutek publicznej umowy lub układu zostaje zmieniony stan drugiego partnera. W takim wypadku ustaje także domniemanie co do trwania stanu posiadania.

Po drugie - trudność sprawia pismo arcyksięcia Karola, w którym ten przyznaje, że kościół gnieźnieński jest matką, a wrocławski córką, prosi matkę o opiekę i względy dla córki, o obronę i troskliwość ${ }^{24}$. Kapituła zauważa w związku z tym, że:

1. Z tego niekoniecznie wynika, iż córka jest matce poddana, skoro spotyka się wiele przypadków, że córka przerasta matkę lub dochodzi do tej samej godności co matka;

2. W okresie niebezpieczeństwa córka wzywała matkę, upraszała jej opieki i pomocy, lecz matka nie wysłuchała błagań córki, potraktowała

W r. 1632 zdobyli wrocławski Ostrów Tumski, znieważając przebywających tu duchownych. W katedrze wrocławskiej odprawiali protestanckie nabożeństwa. Kryptę kościoła św. Krzyża zamienili na stajnię. Zrujnowali też inne kościoły, zniszczyli cenną bibliotekę kapitulną. Por. Urban W., dz. cyt., 190.

${ }^{23}$ Czyli na mocy prawa wskrzeszenia dawnych stosunków w państwie.

24 Ordynariusz Wrocławia arcyksiążę Karol Habsburg (1608-1624), szwagier Zygmunta III Wazy, kołatał u króla polskiego o ratunek w obliczu katastrofy katolicyzmu na Sląsku i likwidacji rządów habsburskich. Zwracal się też do arcybiskupa gnieźnieńskiego Wawrzyńca Gembickiego, przypomniawszy sobie naraz, że diecezja wrocławska należy do metropolii gnieźnieńskiej i arcybiskup powinien pomyśleć o udzieleniu jej pomocy. Wystawił też w związku z tym dwa dokumenty: w Nysie dnia 14. 8. 1619 i w Warszawie dnia 31. 12. 1619. W drugim z nich szczególnie wyraźnie podkreślał prawa metropolitalne Gniezna nad Wrocławiem. Por. Heyne J., dz. cyt., 363-367, 825-826. 
ją jako wyzwoloną lub raczej wydziedziczoną i zamknęła przed nią swe uszy i macierzyńskie piersi, podtrzymując w ten sposób wydziedziczenie, o którym mowa. Z tego powodu córka ma prawo doznawszy obcej opieki oskarżać matkę o nieczułość, osierocenie i wydziedziczenie, a poza tym szczycić się i strzec swej egzempcji nabytej od niepamiętnych czasów i odzyskanej z rąk wrogów dzięki armii cesarskiej iure postliminii oraz powierzonej na nowo królom czeskim ${ }^{25}$. Tu kapituła powołuje się na replikę udzieloną przez Jakuba Schickfusa ${ }^{26}$ i Fryderyka Berga ${ }^{27}$ w związku ze statutami synodalnymi biskupa Marcina Gerstmanna (1574-1585). Replika ta opracowana została na podstawie akt archiwum cesarskiego. We wspomnianym piśmie arcyksięcia Karola kapituła nie widzi rezygnacji $z$ egzempcji, bo:

a. biskup wrocławski nie mógł szkodzić swej diecezji, ponieważ przywilej egzempcji jest przywilejem realnym;

b. zrzeczenie się prawa egzempcji byłoby sprzeczne $z$ przysięgą biskupią, która zobowiązuje go do strzeżenia praw swej diecezji;

c. to zrzeczenie się pociągałoby szkodę nie tylko dla samej diecezji wrocławskiej, lecz także dla całego cesarstwa rzymskiego, w którego interesie leży, by jego poddani nie podlegali czynnikom obcym;

d. choć metropolia gnieźnieńska przed wojną ${ }^{28}$ i za rządów dawnych biskupów rozciągała swoją zwierzchność nad diecezją wrocławską, to jednak prawo to $\mathrm{w}$ wyniku klęski wojennej przeszło na rzecz Królestwa Czech, dzięki któremu diecezja wrocławska odzyskała wolność.

Przeciw próbom ponownego poddania diecezji wrocławskiej zwierzchnictwu Gniezna przemawia pretensja cesarstwa, domagająca się przywrócenia Warmii w Prusach godności senatorskiej na sejmach Królestwa. Dopóki to nie nastąpi, diecezja ta żadnym prawem nie może być wzywana przez metropolię do podporządkowania się, co nie sprzeciwia się zachowaniu prawa apelacji 29 .

W podsumowaniu swoich wywodów kapituła stwierdza, że posiadanie

25 Tu autorowie powolują siẹ na c. 1, X, II, 16 (Placuit), w którym jest mowa o tym, że biskup nawracający jakąś miejscowość na wiarę katolicką pozyskuje ją wskutek przedawnienia po upływie 3 lat.

26 Por. Heyne J., dz. cyt., 364-365 i 785-786.

27 Autor memoriału kapituły z r. 1638. W kapitule wrocławskiej pełnił od 1607 r. funkcje bibliotekarza. Zmarł w 1641 r. w wieku 65 lat. Por. Urban W., Wykaz regestrów dokumentów Archiwum Archidiecezjalnego we Wrocławiu, Warszawa 1970, 6-8.

${ }_{28}$ Chodzi o wojne 30 -letnia w latach $1618-1648$.

29 W oparciu o postanowienia soboru trydenckiego nakazującego diecezjom samodzielnym obranie sobie najbliższego metropolity celem udziału w synodach prowincjonalnych (sess. 24 , c. 2 de ref.) prymasi polscy podejmowali starania o podporządkowanie diecezji warmińskiej metropolii gnieźnieńskiej. 
przez diecezję wrocławską egzempcji nie jest posiadaniem wadliwym, nabytym gwałtem, potajemnie lub nie zwróconym $\mathrm{w}$ razie oddania go na odwołalny użytek ${ }^{30}$, lecz posiadaniem nabytym przez zasiedzenie ${ }^{31}$, z tytułem cesji ${ }^{32}$, manumisji ${ }^{33}$ czy emancypacji ${ }^{34}$. Jakkolwiek by się to określiło, zawsze będzie to tytuł wystarczający, ponieważ do przedawnienia wystarcza nawet tytuł domniemany ${ }^{35}$. Ponieważ zaś przy tego rodzaju zasiedzeniu trudno jest ustalić tytuł, wystarcza w tym wypadku sama dobra wiara przedawniającego ${ }^{36}$. Zaniedbanie ${ }^{37} \mathrm{w}$ tej sprawie na tym polega, że metropolici gnieźnieńscy — zdaniem kapituły — wzywali wprawdzie przedstawicieli diecezji wrocławskiej niekiedy na synody prowincjonalne, lecz kiedy ci odmawiali zasłaniając się egzempcją, nie spotykali się ani $z$ karą przewidzianą w kanonach, nie wytaczano diecezji procesu, nie dokonywano zawiązania sporu, ani też przez jakiekolwiek wezwanie sądowe nie usiłowano przerwać powstającego zasiedzenia. Postępowano tak niewątpliwie dlatego, że zasiedzenie to uważano już za dokonane i nie chciano się obciążać beznadziejnymi procesami. W tym wypadku zatem dla diecezji wrocławskiej wystarczające jest samo korzystanie z egzempcji, o którym metropolici gnieźnieńscy wiedzieli i nie usiłowali mu się przeciwstawić. Taka pobłażliwość wystarcza do uzyskania zasiedzenia nie tylko przywilejów kompetencyjnych, lecz także spraw dotyczących władzy. Protestujący wobec notariusza i świadków albo nie

3* Prawo rzymskie rozróżniało posiadanie słuszne i niesłuszne - possessio iusta ac iniusta - zależnie od tego, czy oparte było na prawnym tytule zdatnym do jego nabycia. W braku tytułu prawnego posiadanie było wadliwe (possessio vitiosa). Possessio vi, clam, precario, od którego odżegnuje się kapituła wrocławska, byłoby posiadaniem wadliwym.

31 Przez zasiedzenie rozumiano nabycie własności skutkiem ciągłego posiadania przez okres czasu przepisany prawem. Warunki tego zasiedzenia - usucapio określał ułożony w średniowieczu heksametr: ,,res habilis, titulusque, fides, possessio, tempus". Obok zasiedzenia zwyczajnego Justynian wprowadził w r. 528 zasiedzenie nadzwyczajne, tzw. longissimi temporis praescriptio, które polegało na tym, że kto objął $W$ posiadanie $w$ dobrej wierze rzecz ruchomą lub nieruchomą i posiadał ją przez lat 30 lub 40 , jeżeli ta rzecz należała do cesarza, Kościoła albo skarbu państwa, to nawet bez słusznego tytułu nabywał na rzeczy prawo własności.

32 In iure cessio była pozornym procesem windykacyjnym wysnutym $\mathrm{w}$ drodze interpretacji przepisu proceduralnego ,.confessus pro iudicato est".

${ }^{33}$ Manumissio oznaczało czynność prawną, na podstawie której właściciel obdarzał wolnością swego niewolnika.

34 Emancipatio oznaczalo uwłasnowolnienie spod władzy ojcowskiej.

25 Titulus putativus zachodzi wówczas, gdy ktoś obejmuje rzecz w błędnym mniemaniu, że ma słuszny do tego tytul, a w rzeczywistości go nie posiada. Tytuł ten tylko wtedy wystarcza do nabycia własności przez zasiedzenie, gdy błąd ten daje się usprawiedliwić, tzn. gdy jest to error probabilis.

${ }_{31}$ Bona fides polega na przekonaniu, że posiadanie rzeczy jest zgodne z prawem. Wymóg ten oparty jest więc na przeświadczeniu, że posiadając rzecz nie popelnia się bezprawia, mimo iż w rzeczywistości posiadacz obiektywnie popełnia bezprawie.

37 Posiadanie prowadzące do zasiedzenia musi być nieprzerwane. Wszystkie wyjaśnienia pojęć prawa rzymskiego czerpiemy z podręcznika W. Osuchowskiego, Zarys rzymskiego prawa prywatnego, Warszawa 1966, $340 \mathrm{nn}$. 
znajdują uznania, albo też cywilnie lub naturalnie usiłują to zasiedzenie przerwać.

Kapituła kończy swoje wywody zapytaniem, jakim prawem mogli sobie rościć pretensje do zwierzchnictwa nad diecezją wrocławską ci, którzy w Królestwie Polskim $\mathrm{z}$ powodu brzemiennych $\mathrm{w}$ skutki przestępstw i spowodowanej tym uchwały kapitulnej stali się niezdatni do objęcia jakichkolwiek beneficjów na ziemi śląskiej. Wiele materiału na ten temat dostarcza - zdaniem kapituly - kontekst memoriału.

Mimo misternie zbudowanej argumentacji przybranej w toge prawniczą, wywody kapituły nie spowodowały rychłego skutku prawnego. Dwór cesarski w Wiedniu, najwidoczniej w poczuciu słabości przytoczonej argumentacji, nie zdobył się na to, by sprawę egzempcji diecezji wrocławskiej przedłożyć do ostatecznej decyzji Stolicy Apostolskiej. Zbyt jasną było rzeczą, że za władzą metropolity gnieźnieńskiego przemawiały mimo wszystko silniejsze motywy prawne, mające swoje uzasadnienie w stanie faktycznym.

Kapituła wrocławska zdawała sobie sprawę, że w świetle faktów i dokumentów historycznych nie da się zaprzeczyć praw metropolity gnieźnieńskiego w stosunku do diecezji wrocławskiej. Dla swoich separatystycznych celów usiłuje zatem znaleźć uzasadnienie w zasiedzeniu czyli nabyciu prawa przez jego faktyczne wykonywanie $\mathrm{w}$ dobrej wierze, oraz $\mathrm{w}$ przedawnieniu jako utracie prawa na skutek faktycznego niewykonywania go przez czas określony ustawą.

Do tego, by nastąpiło nabycie prawa przez zasiedzenie lub utrata prawa przez przedawnienie wymagany jest na pierwszym miejscu przedmiot podlegający przedawnieniu - res habilis, res praescriptibilis. Ogólną zasadą jest, że każda rzecz, która może zmienić właściciela, może być sprzedana, kupiona lub darowana itp. - może także być nabyta drogą zasiedzenia lub przedawnienia, chyba że wyraźnie przez prawo pozytywne cywilne lub kościelne jest spod tego wyjęta. Dekret Gracjana - c. 5, C. XVI, q. 3 - stwierdza wyraźnie, że ,status parochiarum nec praesumptione nec temporum praescriptione mutari potest" ${ }^{38}$. Kapitule nie był ten przepis nieznany, usiłuje go jednak w swoim memoriale interpretować w ten sposób, że chodzi w nim jedynie o sytuację, gdy na skutek przedawnienia następuje zatarcie granic. Interpretacja taka wydaje się jednak zbyt poszerzona.

Do warunków koniecznych dla zasiedzenia czy przedawnienia należy także czasokres legalnego posiadania jakiejś rzeczy - tempus reguisi-

38 Por. też c. $9, \mathrm{X}, \mathrm{II}, 26$ oraz c. $4, \mathrm{X}, \mathrm{III}, 29$. 
tum - przy czym gdy idzie o nabycie posiadania drogą przedawnienia, musi to być czas ciągły - tempus continuum - nie ulegający przerwie czy zawieszeniu. Według dawnego prawa - c. 9. 15, C. CVII, q. 2; c. 3, X, de praescr., II, 26 - rzeczy nieruchome nie należące do Stolicy Apostolskiej ulegały przedawnieniu po 40 latach.

Kapituła wrocławska w omawianym dokumencie podaje, że metropolici gnieźnieńscy od stu lat nie mogą się wykazać nawet jednym aktem swej władzy w stosunku do diecezji wrocławskiej. Czy stwierdzenie takie jest rzeczywiście zgodne $\mathrm{z}$ prawdą? Oto w roku 1557 i 1561 przedstawiciel biskupa Baltazara $\mathrm{z}$ Promnicy wziął udział w synodach prowincjalnych, a prawie $\mathrm{w}$ każdym wypadku biskupi wrocławscy usprawiedliwiali swoją nieobecność na synodzie i ogłaszali w swej diecezji statuty synodów prowincjonalnych. Dowodem ścisłej łączności z metropolią było też przyjęcie przez biskupów wrocławskich rytuału i patronału polskiego w księgach liturgicznych ${ }^{39}$. Biskup Marcin Gerstmann przyjąl zaproszenie na synod prowincjonalny w Piotrkowie w 1577 roku, ale nie wysłał delegata $z$ powodu sprzeciwu kapituły. Natomiast przyjął i ogłosił na synodzie wrocławskim w. 1580 roku statuty synodu piotrkowskiego. Podobnie biskup Andrzej Jerin (1585-1596) otrzymał od arcybiskupa gnieźnieńskiego Stanisława Karnkowskiego zaproszenie na synod prowincjonalny w Piotrkowie w 1589 roku. Nie wysłał jednak przedstawiciela ze względu na tron habsburski, który niechętnym okiem patrzył na przypominanie starych praw metropolitalnych. Sprawa przynależności Wrocławia do Gniezna poruszana też była na synodach prowincjonalnych w 1628, 1634 i 1638 roku ${ }^{40}$. Niemało kłopotu sprawiło kapitule — jak stwierdziliśmy wyżej - wyjaśnienie dokumentu arcyksięcia Karola Habsburga z 1619 roku, w którym uznaje on arcybiskupa gnieźnieńskiego za swego metropolitę.

Niemniej kłopotliwe musiało być dla kapituły wrocławskiej potwierdzenie papieża Urbana VIII o przynależności Wrocławia do polskiej prowincji kościelnej, jak to wynika $\mathrm{z}$ akt synodu prowincjonalnego z 1634 roku: ,praesertim cum et ipse Summus Pontifex modernus illam Ecclesiam (Vratislaviensem) Gnesnes, Sufraganem, in litteris suis, coram synodo lectis, agnoscat" ${ }^{41}$. Biskup wrocławski Karol Ferdynand w imieniu swoim i kapituły katedralnej nie omieszkał w takiej sytuacji usprawiedliwić swej nieobecności na tymże synodzie. Jego usprawiedliwienie wprawdzie zostało przyjęte do wiadomości, ale równocześnie synod zażądał od niego urzędowego oświadczenia, że uznaje jurysdykcję metro-

39 Kumor B., dz. cyt., 13.

40 Urban W., Zarys dziejów..., 20-26.

41 Synodus provincialis Gnesnensis provinciae sub Joanne Wężyk Archiep. Gnesn. a. D. 1634 celebrata, Cracoviae 1636, cap. 10. 
polity gnieźnieńskiego nad diecezją wrocławską ${ }^{42}$. Papież Urban VIII bullą Militantis Ecclesiae regimini z dnia 20 września 1635 roku zatwierdził statuty tego synodu wraz ze statutem o przynależności Wrocławia do metropolii gnieźnieńskiej, a biskup Karol Ferdynand złożył na piśmie w dniu 10 lutego 1637 roku uroczyste oświadczenie w imieniu swoim i swoich następców, że biskupstwo wrocławskie podlega arcybiskupowi gnieźnieńskiemu jako swemu metropolicie. Dokument ten został włączony do Akt czynności prymasa Jana Wężyka. Synod prowincjonalny prymasa Macieja Łubieńskiego z 1643 roku znowu przypomnial biskupowi wrocławskiemu obowiązek obecności na synodzie ${ }^{43}$.

Jeśli akty władzy metropolitów gnieźnieńskich w stosunku do diecezji wrocławskiej są mimo wszystko nikłe, to dlatego, że nie mogli oni po prostu wykonywać swych uprawnień z powodu silnych przeszkód stawianych przez władzę cesarską i będącą pod jej wpływami kapitułę katedralną wrocławską. Dlatego metropolici ograniczali się do przypominania jedynie swych praw metropolitalnych z okazji zwoływania synodów prowincjonalnych. W takim jednak wypadku czasokres zasiedzenia czy przedawnienia nie był czasem ciągłym - tempus continuum, lecz czasem użytecznym - tempus utile, który nie upływa, jeśli zachodzą przeszkody do spełnienia czynności, jaka jest potrzebna do wykonania swego prawa.

Autorzy omawianego dokumentu powołują się w swoich wywodach na opinię Augustyna Barbosy (1589-1649). Barbosa jest cenionym autorem różnych dzieł z zakresu prawa kanonicznego ${ }^{44}$. Powoływanie się jednak na opinię tego autora jest w omawianej kwestii bezprzedmiotowe. Barbosa daje komentarz do postanowień soboru trydenckiego, ale wyjaśnienia jego bynajmniej nie przemawiają na korzyść stanowiska kapituły wrocławskiej, usiłującej za wszelką cenę znaleźć podstawę prawną do wyłamania się spod władzy metropolity gnieźnieńskiego. Tak na przykład szczegółowo zajmuje się on wniesieniem i rozpatrzeniem apelacji od wyroku biskupiego, przy czym podaje, że należy stosować się do obowiązujących przepisów. Wyjaśnia, że metropolita nie powinien sądzić spraw swoich sufraganów i ich podwładnych, jak tylko w wypadkach przewidzianych przez prawo. Opinie Barbosy na omawiane tematy nie odbiegają w zasadzie od poglądów innych kanonistów, a cytowanie tego autora przez kapitułę wrocławską nie wnosi do zagadnienia nic nowego. $\mathrm{Z}$ tekstu przebija raczej chęć wykorzystania wielkiego autorytetu Barbosy dla uzasadnienia tendencji odrzucenia zwierzchności metropolity gnieźnieńskiego, a nie dla obiektywnego naświetlenia sprawy.

42 Tamże.

43 Kumor B., dz. cyt., 14-15.

44 Zob. Kurtscheid B., Wilches F. A., Historia iuris canonici, t. 1, Romae 1943, 286. 
Tendecja ta leży również u podstaw drugiej konkluzji kapituły, st ierdzającej, że diecezja wrocławska korzysta z uzyskanego na drodze przedawnienia prawa egzempcji. Konkluzja tego rodzaju stanowi jedynie dowolny wniosek, będący wyrazem dążeń elementów niemieckich w kapitule. Dodajmy, że szereg stanowisk w kapitule zajmowali już wychowankowie kolegium w Rzymie, tzw. Collegium Germanicum, założonego w 1555 roku specjalnie dla kształcenia duchownych niemieckich, w tym również Ślązaków. Z kolegium tego wychodzili bojownicy kontrreformacji ale zarazem niemczyzny, oraz wierni słudzy domu Habsburgów, uważanego wówczas za główną ostoję katolicyzmu ${ }^{45}$. Nie ulega wątpliwości, że walka kapituły o usamodzielnienie biskupstwa wrocławskiego od Gniezna była równocześnie zacieraniem śladów dawnego zwierzchnictwa polskiego nad Śląskiem.

Historiograf Śląska ubolewa nad tym, że w polityce polskiej XVI i XVII wieku nie wyzyskano zupełnie wyjątkowo korzystnego momentu, gdy można było odzyskać prastare ziemie polskie nad Odrą. Pozwolono Niemcom rozegrać swoje konflikty wewnętrzne, nie niepokojąc ich zupełnie. Polityka polska w tym okresie pochłonięta całkowicie sprawami utrzymania i obrony niezmiernie wydłużonej granicy wschodniej i południowo-wschodniej, odwróciła się od problemów zachodnich. W Polsce cieszono się po prostu, że na razie od strony zachodniej nie grczi bezpośrednie niebezpieczeństwo, gdyż Niemcy pogrążały się coraz bardziej w zamęt wyznaniowy i rozstrój polityczny ${ }^{46}$.

W podsumowaniu wszystkiego podkreślmy raz jeszcze nasuwające się najważniejsze wnioski:

1. Dokument pod literą F z dnia 5 czerwca 1654 roku, dołączony do memoriału kapituły wrocławskiej przekazanego cesarzowi Ferdynandowi III stwierdza jako rzecz niewątpliwą dawną przynależność diecezji wrocławskiej do metropolii gnieźnieńskiej.

2. Kapituła uważa za rzecz pewną, że w omawianym okresie metropolita gnieźnieński nie posiadał już praw metropolitalnych nad Wrocławiem, ponieważ utracił je na podstawie przedawnienia, a diecezja wrocławska uzyskała prawo egzempcji na zasadzie zasiedzenia.

3. Argument, jakoby nastąpiło to dlatego, że metropolita gnieźnieński od co najmniej stu lat nie wykonał żadnego aktu swoich uprawnień, jest dowolnym wnioskiem. Stan faktyczny wykazuje, że z powodu trudności natury politycznej metropolici zmuszeni byli do przypominania jedynie swych praw metropolitalnych.

4. Dokumenty biskupa Karola Habsburga z 1619 roku stwierdzające w sposób niezbity zależność metropolitalną Wrocłaria od Gniezna kapi-

\footnotetext{
45 Piwarski K., dz. cyt., 192.
}

46 Tamże, 187. 
tuła interpretuje w sposób dowolny, a zasadniczą ich treść odrzuca jako nie do przyjęcia.

5. Stanowisko kapituły wrocławskiej z 1654 roku jest wyrazem tendencji elementów niemieckich do wyłamania się spod władzy metropolity polskiego. Ponieważ kapituła zdawała sobie sprawę, że zamiarów swoich nie zdoła przeprowadzić na gruncie kościelnym, usiłowała przerzucić caly problem na teren polityczny i szukała poparcia nie u papieża, lecz u cesarza.

\section{TEKST ZAEĄCZNIKA F}

PRZY MEMORIALE KAPITUEY WROCEAWSKIEJ Z DNIA 5. 6. 1654.

Deutsches Zentralarchiv Merseburg rps sygn. R. 46 B n. 164e, f. $278-287$ v. [f. 278] Quaestio

In quibus punctis renovetur per Concilium Tridentinum metropolitani Gnesnensis authoritas et subiectio episcopi Wratislaviensis metropolitanae legi.

1. Renovatur 1 Sess. 13, c. 2, ubi expresse statuitur quod a sententia episcopi, vel ipsius in spiritualibus vicarii generalis, in criminali appellationis causa per Pontificem committi debeat metropolitano seu illius in spiritualibus vicario generali, et secundum hoc concilium fuit resolutum, non posse eiusmodi causam auditoribus nun [f. 278 v] ciorum committi (Barbosa ibidem).

2. Item 2. Renovatur sess. 22, c. 7, ubi disponitur quod in appellationibus debeat servari tenor c. Romana de appellationibus in 6, ubi dicitur quod a vicario generali episcopi ad archiepiscopum appellari debeat, quoniam proximus superior episcopi est archiepiscopus (c. 1, de officio ordinariorum in 6).

3. Sessione 23 , c. 1 de reform. metropolitano committitur, ut faciat inquisitionem super residentia episcoporum (Barbosa 1 in d. c. 1).

4. Sessione 24 , c. 2 de reform. statuitur, quod concilia provincialia debeant singulis trienniis fieri, et ad eorum observantiam cogi comprovinciales episcopi, non obstante lapsu decennii, quo non fuerunt observata (Garxias de benef., p. 5, c. 4, n. 103).

Barbosa in d. 1 ait comparationem episcopi coram metropolitano semel factam non posse mu [f. 279] tari per episcopum.

5. Sessione 24 , c. 3 , datur metropolitano facultas cognita in provinciali concilio causas dioecesseos suorum comprovincialium episcoporum etiam rite et plene visitatas iterum visitandi (Barbosa ibidem, n. 11), assumpto tamen notario cum consensu episcopi.

6. Sessione 24 , c. 5 de reform. subiciuntur causae episcopales maiores Pontifici, minores concilio provinciali vel ab ipso deputandis.

7. Sessione 24 , c. 16 statuitur, quod vacante sede debeat constitui a capitulo vicarius seu oeconomus, qui futuri episcopi sit syndicatui subiectus et cessante per octiduum capituli deputatio ille debeat devolvi ad metropolitanum.

8. Sessione 24 , c. 20 causae ecclesiasticae debent im prima instantia tractari coram ordinario et finiri intra biennium, sub poena devolutionis ad metropolitanum. 
In quibus autem consistat authoritas metropolitani et comprovincialium subiectio, late tradit (Barbosa, de officio et potestate episcoporum, p. 1 c. 4, n. 3).

[f. 279 v] Quaestio: Utrum possit episcopatus Vratislaviensis suam exemptionem contra Gnesnenses iure manutenere.

Conclusio 1. Episcopatum Vratislaviensem pertinuisse ab antiquo et fuisse sub archiepiscopatu Gnesnensi indubitatum est, idque probatur partim per synodum Martinianum, patrim per matriculam episcopatuum omnium (apud Rebustum, partim apud Barbosam, de officio et potestate episcoporum, p. 1, tit. 1).

Conclusio 2. Certum est archiepiscopatum Gnesnensem moderno tempore non esse in possessione istius iuris suffraganealis episcopatui Vratislaviensi, sed potius episcopatum Vratislaviensem esse in possessione exemptionis, quia a centum et quod excedit annis non potest Gnesnensis unicum actum allegare possessorium.

Nam 1-o: Quamvis conveniebat ut electum Vratislaviensem confirmaret archiepiscopus (c. 1, distinct. 64, c. Innotuit, c. Cum dilectus, de elecione; c. Inter corporalia, et de translatione episcopi, Qua fronte, de appellationibus; Quaranta in Summa Bul [f. 280] larii, p. 6, Archiepiscoporum authoritas n. 3), tamen non potest doceri, quod archiepiscopus Gnesnensis talem potestatem in episcopatu Vratislaviensi a plus 40 et quod excedit annis exercuerit, aut quod eidem ex parte Vratislaviensi partitum sit.

2-o: Quamvis ad consecrationem metropolitani omnes suffraganei episcopi concurrere debeant (c. Qui in aliquo, distinct. 51; c. Si archiepiscopus, et de tempore ordinationum: Quaranta d. 1 n. 4), tamen Vratislaviensem episcopum in aliquot actibus a 40 annos exercitis neque citatum fuisse, neque comparuisse manifestum est.

3-o: Quamvis suffraganeus episcopus, qui in metropolitana civitate non fuit ordinatus, intra tres menses proprii metropolitani praesentiam visurus pro instructione monitorum archiepiscopi accedere aut se excusare debeat proposito legitimo impedimento (C. Cum longe, distinct. 63; c. Si quis, distinct. 65; Quaranta d. 1, n. 5), attamen non potest demonstrari, quod Vratislavienses episcopi hoc praestiterint, aut quod ab eius iuris omissionem a metropolitano unquam ad eiusdern executionem moniti sint.

[f. 280 v] 4-o: Quamvis srchiepiscopus suis suffraganeis iniungere debeat servari id, quod servatur in metropolitana (c. Dilectus, et de simonia; Quaranta d. 1, n. 7), attamen non potest remonstrari, quod a 40 vel 60 et quod excedit annis unquam Gnesnensis hac potestate usus fuerit.

5-0: Quamvis archiepiscopus debeat probare in scriptis absentiam episcopi suffraganei (Concil. Trident. sess. 6 de reform. c. $3^{\text {a }}$, et sess. 21b de reform. c. 1; Quaranta in Summa Bullarii d. n. 7),

quod factum esse nemo Vratislaviensium canonicorum meminit, neque ex registris simile quid apparet.

6-0: Quamvis metropolitanus possit punire a consuetudine metropolitanae ecclesiae in divinis officiis deviantes (c. De iss, distinct. [12]c; Quaranta in Summa n. 22), neque tamen a 40 vel 60 annis hac potestate Gnesnensem usum fuisse, doceri potest in cathedrali [f. 281] Vratislaviensi.

7-0: Licet archiepiscopus tanquam Sedis Apostolicae delegatus convocare regulares possit, in cuius provincia sub immediata Sedis Apostolicae protectione siti sunt, et negligentes exequi iuxta decretum s. concilii Tridentini (sess. 25 de regul.

a Winno być: c. 1 de ref.

b Winno być: sess. 23 c. 1 de ref.

c Brak podania numeru dystynkcji. 
c. 8; Quaranta d. 1, v. 5, n. 37), attamen neque hac facultate a centum et quod exedit annis usum fuisse probari per Gnesnessem potest.

8-o: Quamvis archiepiscopus possit deputare vicarium seu officialem in ecclesia suffraganea, si infra octo dies post mortem episcopi capitulum non elegerit aliquem idoneum officialem (sess. 24 de reform. c. 16; Quaranta d. 1, n. 36), et licet saepius vacaverit sedes episcopalis Vratislaviensis et nunquam talem actum exercuerit Gnesnensis, ideo satis apparet, quod episcopatus Vratislaviensis suam exemptionem legitime praescripserit, et in possessione exemptionis existat.

9-o: Quamvis ab episcopo ad archiepiscopum appel [f. 281 v] lari debeat (Quaranta in Summa d. 1, n. 13), tamen a centum et quod excedit annis nulla est interposita appellatio ad archiepiscopum Gnesnensem, sed ad illustrissimum dominum nuncium ideoque rursus patet praescriptio, maxime cum in nullo superiorum actuum neglectorum et abs exempta nostra cathedrali exercitorum ulla appareat contradictio, contra protestatio, aut contra intentata actio, neque a tot annis potest praetendi ulla ignorantia Gnesnensis.

Cum igitur de naturali possessione exemptionis episcopatus Vratislaviensis nulla sit difficultas, civilis vero etiam decennio amittatur, ideo paret Gnesnensem episcopatum non esse in possessione dominii metropolitici supra episcopatum Vratislaviensem.

Quamvis sess. 24, c. 2 statuitur, quod concilia provincialia debeant singulis triennis fieri et ad eorum observantiam comprovinciales episcopos cogi, non obstante lapsu decennii, quo non fuerunt observata (Garxias, De benefic. p. s. c. 4, n. 103), attamen neque in hoc casu archiepiscopum sua [f. 282] praetensa potestate usum fuisse. Sed cathedralem hanc pro manutenenda sua exemptione ab iis liberrime et sine ulla contradictione Gnesnensis in hane horam emansisse compertum est, sed demonstrari potest, quod nimirum infinitos actus exemptionis Vratislaviensis episcopus exercuerit et sic legitima praescriptione ius exemptionis acquisiverit, nam in hoc nostro casu fuerunt complura concilia celebrata, et ultra 40 annos nunquam episcopus Vratislaviensis ad illa coactus aut convocatus aut comparuit, neque potest dici, quod haec exemptio irrationabilis sit, cum eam propter continua bella, quae inter Matthiam Hungariae Bohemiaeque regem, et Casimirum Poloniae regem 1498d intercedebant, suaserit transquillitas patriae et pax publica Germaniae, quae per polonicos ministros proditione consiliorum huius provinciae adeo turbabatur ut etiam publicum statutum sub Rudolpho episcopo Vratislaviensi in capitulo generali factum, quo propter praefatam causam et morum linguaeque diversitatem omnibus Polonis, inque subiacentibus Poloniae provinciis oriundis fuit interdictus accessus ad canonicatus et capitula cathedralis ecclesiae Vratislaviensis [f. 282 v] et quidem ad instantiam serenissimi regis Hungariae et Bohemiae Mathiae de data Cornenburg in die ss. Innocentium anno 1474, ubi per hortatur episcopus Vratislaviensis ne ullum Polonorum, vel ex ea patria oriundum ad quaecunque et qualiacunquae beneficia in ipso ducatu Silesiae existentia recipiat vel admittat. In quo rescripto etiam continetur, quod Sua Serenitas Summum Pontificem desuper rogaverit, ne provideantur, aut promoveantur Poloni ad Silesiacae beneficia, quia plerique nostribus regni et ducatus huius favoris praestiterunt.

Neque est hoc novum, quod propter diversitatem regionum, morum et linquarum, non permittantur episcopatus alieno metropolitano subesse, prout etiam in Hispania, Gallia et inferiori Germania observatur, imo et in Polonia, in qua non

d Winno być: 1478;

e Silesia o a kop.; 
reperitur ullus episcopatus, qui metropolitano alterius regni sit subiectus, prout patet ex matricula episcopatuum.

Et quamvis sub patriarchatu Aquiliensi sint diversorum ducum et regionum episcopatus, tamen omnes sunt eiusdem linguae, sic nec [f. 283] etiam obstat, quod sub archiepiscopatu Trevirensi, Metensi, Tullensi, Verdunensi episcopatus comprehendatur iuxta matriculam episcopatuum, supra insinuatam, hoc tamen tum constitutum fuit, quando praedicti episcopatus arhuc ad Romanum Imperium spectabant, postquam vero rex Galliae hoc sibi armis asseruit, Trevirensis parum potestatis in illos sibi retinuit, usque dum per instrumentum pacis cum Gallorum rege specialiter erectum reservatum fuit Trevirensi episcopo ius suum metropoliticum, quod in Polonica transactione nullibi reperitur, sed per renunciationem regiam.

Nec obstat, quod finesf dioecesium prohibentur praescribi (c. Super eo et de Parochis, c. Quicunque et licet 16 qu. 3; Barbosa, de potestate episcoporum, p. 3, alleg. 131, n. 4). Quia hoc intelligitur, quando ex illa praescriptione oritur finium confusio, quae hic non est metuenda (Barbosa d. p. 3, alleg. 131, n. 6), nisi hic episcopatus retrahatur, aut evocentur subditi ad Gnesnensem superioritatem, longe extraneam [f. $283 \mathrm{v}$ ] moribus et lingua diversam.

Ad hanc confusionem praecavendam, in constitutionibus synodalibus Vratislaviensibus fuit expresse statutum, ne huius dioecesis Vratislaviensis homines spirituales, vel saeculares vexentur ad sumptusg graves et inutiles, nec non ad periclitationem rerum et corporum propter viarum et locorum varia discrimina, quod nullus presbyter, curatus et non curatus, aut notarius publicus mandata peregrina extra dioecesim Vratislaviensem emanata, sine mandato episcopi Vratislaviensis, aut vicarii eiusdem acceptare, sive executionem eorundem procurare, seu in ecclesiis affigi facere, sed portatores huiusmodi mandatorum et nuncios ad episcopum Vratislaviensem, vel eiusdem in spiritualibus vicarium remitttere debeat, sub poena synodali.

Ad haec addendum videtur, quod in Polonia episcopi debeant subiacere terrestribus iudiciis in causis forensibus, prout de episcopo Plocensi constat, ex consensu infra allegato. Cum igitur episcopus Vratislaviensis non modo in forensibus negotiis subiaceat regi Bohemiae ligio nexu, sed et privilegio pontificio tota Germania in beneficialibus et eiusmodi simi [f. 284] libus fruatur concordatis Germaniae, ideo non potest eiusmodi res controversa alibi, nisi inter Germanicos eius iuris consortes, decidi, et ad exteros eius iuris neque consortes, neque gnaros iuxta c. Romana de appellationibus minime devolvi, praesertim cum rex Bohemiae multa singularia habeat privilegia, etiam Pontificia indulgentia concessa, quorum cum Gnesnensesh nullam rationemi habeant, frustra arrogant sibi cognitionem, tam in secunda, quam in prima instantia, sicut et Germanus faceret, qui regni Poloniae privilegiis ignoratis causae cognitionem Polonicae usurparet.

Praeterea cum publico pacto inter Johannem Bohemiae et Casimirum Poloniae reges, arbitro Carolo Ungariae rege, anno 1335 inito, Silesia avulsa sit a Polonia et cessa sit Germaniae, dein anno (...)j incorporata Bohemiae cum omnibus iuribus et privilegiis suis, qua cessione universali, sicut ius patronatus ecclesiarum transit in solidum (Riccius decis. 179), nisi nominatim exceptum fuerit (Vallen. in Paratitlis Iuris Canonici, de iure patronatu $\S 4, n .1)$ [f. $284 \mathrm{v}$ ] a cedente in cessionarium,

f fides kop.;

g sumtus kop.;

$\mathrm{h}-\mathrm{i}$ nullam nullam nationem kop.;

j luka na 4 litery, opuszczono rok; chodzi o rok 1339. 
sic et exemptio a superioritate cedentis omne ius (Argumento a verisimili). Cessio enim manumissioni comparatur, quae liberat subiectum a iure subiectionis, sicut servum a iure dominicae potestatis, quo collimat (Goldastus lib. 5, c. 6 apud Münsterum). Quae cessio sive manumissio magis hic attendenda, quam negari nequit, eam cum consensu Gnesnensis Archiepiscopi tanquam Primatis Regni factam esse.

De quo consensu eo magisk constat, quia ab illo tempore Polonia senatoriam in ea dignitatem episcopis Vratislaviensibusl iure nativo et haereditario competentem nostratibus episcopism Vratislaviensibus denegavit, quod sine consensu Primatis fieri nequit, imo et in hanc horam denegat, atque sic episcopatum Vratislaviensem, debita dignitatis et haereditatis portione privat, quae privatio exhaereditationi utique comparatur. Exhaereditatio autem non etiam filium a patria potestate liberat, et illa potestas proculdubio ad iniuriae [f. 285] exhaeredationis affectum transit, sicut ius patronatus ecclesiam a patrono iniuria affectum (Vallen. in Paratitlis Iuris Canonici, de iure patronatus $\S 7$, n. 1).

Constat insuper episcopatum hanc Vratislaviensem in hostium potestatem devenisse, et quidem acatholicorum occupata eiusdem cathedrali summana insula et residentiae episcopalis civitate, atque sic in discrimen iurium suorum pervenisse iuxta textum. Quare cum armis caesareis postliminii iure sit vindicatus in libertatem et regno Bohemiae tacite iterum incorporatus cum omnibus iuribus ab hostibus interceptis et Marte imperiali recuperatis, etiam sine ullo Gnesnensis archiepiscopatus subsidio, aut regni Poloniae auxilio, nisi aere imperiali conducto. Frustra Gnesnensis huius vendicationis praemium nequaquam sibi vendicat, cum neque de sudore participavit, neque expensas ad eam recuperationem contulerit.

Demum quis non mirabitur, a Gnesnensi episcopo et Poloniae proceribus hunc episcopatum suffraganeatus iure vendicari in subiectionem Polonicam, qui novit Poloniam Imperii Romani tutelae et superioritati subiectam, Prussiam et cum ea Warmiensem ${ }^{n}$ episcopatum de quo supra plenius, in- [f.285 v] tervertisse, et interversam adhuc actu detinere, proinde etiamsi aliquot ius superioritatis in episcopatum Vratislaviensem praetendere posset, attamen scire debet hanc suam praetensionem reconventionis iure licite elidi posse neque dum Polonia cedat Prussiam, Warmiensemo episcopatum, et episcopatui huic sibi in Polonia competentem senatoriam in comitiis dignitatem postliminii iure restituat.

In contrarium quidem obicitur Gnesnensem episcopatum olim in possessione fuisse superioritatis quoad hunc episcopatum, ergo et iam adhuc esse praesumi, quamvis enim hoc argumentum in iure satis firmum sit, tamen patitur suas exceptiones, inter quas una est, cur per publicam conventionem aut transactionem status alterius mutatus esse dignoscitur, quo casu etiam praesumtio cessat continuatae possessionis.

Secundo obiicitur serenissimi archiducis Caroli scriptum, in quo fatetur Gnesnensem ecclesiam esse matrem, Vratislaviensis filiam imploratur pro filia a matre tutelam et protectionem, praesidium et patrocinium, sed animavertendum:

1-mo. Inde non necessario concludi, filiam ma [f. 286] tri esse subiectam, cum plures casus existent, quibus filia in maiorem dignitatem, aut parem cum matre excreverit.

2-do. Notandum cum tempore illo periculosissimo filia ad matrem proclamavit,

k majis kop;

l-m powtórzono w kop.;

n Warmientem kop.;

o Warmioens. kop.; 
tutelam expetierit, et subsidiariam in naufragio manum, mater vero filiae inclamantis preces non exaudierit, sed manumissae, vel potius exhaeredatae filiae aures benignas et materna ubera clauserit, atque sic exhaecdationem, de qua supra, continueritp, quod ob id filiae fas sit alieno patrocinio eluctante, maternam duritiem, praeteritionem et exhaeredationem inculpare, et suam exemptionemq abs immemoriali tempore quaesitam et Marte imperiali assertam abs hostibus postliminii iure recuperatam magnifacere et tueri, et Bohemiae regibus acceptam facere, vide c. Placuit et de praescriptione, ubi asseritur, quod episcopus convertens quendam locum ad fidem catholicam praescribat illum triennio (Barbosa in distinctione c. „Placuit”).

Demum adducuntur multa ex synodalibus Martini episcopi statutis, sed hisce iam pridem responsum est a Schickenfusio et Bergio, iuxta acta in archivo imperiali reperta, ad quae addi potest, quod:

1. Episcopus Vratislaviensis [f. 286 v] non potuit praeiudicare suae ecclesiae, quia privilegium hoc est reale.

2. Est contra iuramentum episcopale, quo obligatur ad iura ecclesiae suae manutenenda.

3. Quia praeiudicium huius ecclesiae non modo redundat in dispendium solius ecclesiae, sed et totius Romani Imperii, cuius interest, membra habere sibi subiecta non exteris.

4. Etiamsi Gnesnensis ecclesia ante hoc bellum et tempore praefatorum dominorum episcoporum fuisset adhuc in possessione suae superioritatis et subiectionis huius episcopatus, tamen hoc ius per bellicam captivitatem amisisset, et regno Bohemiae cessisset, cuius manu forti, de abs hostibus in libertatem assertam esse meminit.

Demum obstaret agenti ad subiectionem huius episcopatus reconventio Imperii Prussiam Warmiam reposcentis et restitutionis in pristinum ordinem senatoriae dignitatis in comitis regnir, quousque nullo iure hic episcopatus a Gnesnensi in subiectionem revocari nequit, obstante exceptione reconventionis.

Coronidis loco addimus, quod nos usi simus hoc iure exemtionis non vi, nec clam, nec [f. 287] precario, per legitima temporis continui spatia, et quodam titulo cessionis, sive manumissionis, sive emancipationis, quomodocunque tandem is nomine vocatur, qui utique sufficit cum praescriptionibus etiam solus titulus putativus sufficiat (Vallen. in Paratitlis 1. Decret. tit. de praescriptionibus $\S 18$, n. 2, 1 sin. iungatur Pro legato; Honorius ab Alexandro in Compendium Iuris Canonici; Barbosa de praescriptione n. 25). Imo etiam, quia in eiusmodi longissimi temporis praescriptionibus titulus ne quidem requiritur, sed sufficit sola bona fides praescribentis (Covar. ad Reg. Possess. § 1, n. 7; Vallen. d. 1 tit. de praescriptione $\S 5$, n. 4).

Negligentia vero ex eo subinde patet, quod Gnesnenses equidem nostrates semel vel iterum ad synodum provincialem nostrates citarint, sed recusantibus nostris et exemptioni suae inhaerentibus neque ad poenam in canonibus praescriptam egerint, neque litem nostrae ecclesiae moverint, neque litis contestationem, et neque quidem per citationem [f. $287 \mathrm{v}$ ] ullam iudicialem praescriptionem nostram infringere tentarint, procul dubio, quis iam completam existimarunt, et frustraneis litibus se onerare noluerint.

Denique, utique sufficiet ecclesiae nostrae usus exemptionis suae, cum illum

p continuarit kop.;

q exemtionem kop.;

$r$ Regiis kop.; 
sciverint Gnesnenses et acquieverint, quae ac patientia sufficit ad praescribendum non modo iure canonis privilegio competentia, sed etiam ad res mere facultatis praescribendas per ea quae tradit (Gail. Observat. 14, n. 4-. Quae patientia procul dubio sufficiens est, necne quidem coram notario et testibus contra protestati dignoscantur vel civiliter aut naturaliter interrumpere tentarint.

Demum quo iure poterunt ii superioritati praetendere, qui praedicto rego ex causa praegnantissima delictorum enormissimorum et desuper subsecuto statuto ecclesiae nostrae se incapaces reddiderunt beneficiorum omnium in hac patria nostra, de quibus edictis et statutis plura in contextu relationis continentur.

\section{LA DÉPENDANCE DU DIOCÉSE DE WROCEAW DE LA MÉTROPOLE DE GNIEZNO}

$R$ és u mé

Par suite du synode diocésain de Wrocław qui avait eu lieu à Nysa en 1653, le chapitre de Wrocław prépara un mémorial dans lequel, en date du 5 juin 1654, il exprime, dans l'un de ses annexes (F), son opinion sur le problème de la dépendance du diocèse de Wrocław de la métropole de Gniezno.

On y constate comme indubitable l'ancienne appartenance du diocèse de Wrocław à la métropole de Gniezno. En même temps on considère comme une chose sûre et certaine que, dans la période mentionnée, le métropolite de Gniezno ne possède plus de droits métropolitains sur Wrocław, les ayant perdus à cause de la prescription, tandis que le diocèse de Wrocław gagne le droit d'exemption en vertu de l'usucapion. Selon l'opinion du chapitre, cela fut causé par le fait que le métropolite de Gniezno n'avait exécuté depuis cent ans, au moins, aucun acte affirmant son autorité.

L'état réel de choses montre que c'était à cause des difficultés de nature politique que les métropolites de Gniezno se voyaient forcés à faire rappeler seulement leurs droits métropolitains.

L'attitude du chapitre de Wrocław à ce sujet était l'expression des tendances des éléments allemands à se soustraire au pouvoir du métropolite polonais. 